\title{
Polymorphisms in BER genes and risk of breast cancer: evidences from 69 studies with 33760 cases and 33252 controls
}

\author{
Lele Qiao ${ }^{1, *}$, Xiaoshan Feng ${ }^{1, *}$, Gongping Wang ${ }^{1}$, Bo Zhou ${ }^{1}$, Yantong Yang $^{1}$ and \\ Mengxiang $\mathbf{L i}^{2}$ \\ ${ }^{1}$ The First Affiliated Hospital and College of Clinical Medicine of Henan University of Science and Technology, Luoyang, \\ 471003, China \\ ${ }^{2}$ Henan University of Science and Technology, LuoYang, Henan, 471023, China \\ *These authors contributed equally to this work and should be considered as co-first authors \\ Correspondence to: Lele Qiao, email: lianghe201610@163.com \\ Xiaoshan Feng, email: samfeng137@hotmail.com
}

Keywords: BER gene; breast cancer; polymorphism; meta-analysis

Received: June 27, 2017 Accepted: November 27, 2017 Epub: January 02, 2018 Published: March 23, 2018

Copyright: Qiao et al. This is an open-access article distributed under the terms of the Creative Commons Attribution License 3.0 (CC BY 3.0), which permits unrestricted use, distribution, and reproduction in any medium, provided the original author and source are credited.

ABSTRACT

Recently, numerous studies have reported an association between single nucleotide polymorphisms in base-excision repair genes and the risk of developing breast cancer, however there is no consensus. The aim of this meta-analysis was to review and quantitatively assess the relationship between single nucleotide polymorphisms in base-excision repair genes and breast cancer risk. The results suggested that a mutation of $\mathrm{T}$ to $\mathrm{G}$ in rs1760944 may lead to a higher risk of developing breast cancer in the Mongoloid population, and G to A of rs25487 significantly reduced the risk of breast cancer in Mongoloid and Caucasoid populations. In contrast to the CC and CG genotypes, the GG genotype of rs 1052133 located on theOGG1 gene appeared to be a protective factor against developing breast cancer in both Mongoloid and Caucasoid populations. There was no evidence to suggest that rs25489, rs1799782, rs1130409, rs1805414 and rs1136410 were associated with breast cancer risk. In conclusion, this study provides evidence to support the theory that DNA repair genes are associated with breast cancer risk, providing information to further understand breast cancer etiology. and The potential biological pathways linking DNA repair, ethnic background, environment and breast cancer require further investigation.

\section{INTRODUCTION}

-Breast cancer (BC) affects about $12 \%$ of women worldwide. Statistics indicate that almost 3 million women suffers from BC in 2015 in the United States [1]. Risk factors for developing breast cancer include unhealthy lifestyles, other medical conditions and genetic susceptibility [2, 3]. Epidemiologic studies suggest that women with family history of BC could be more vulnerable to develop $\mathrm{BC}$ cancer than those not $[4,5]$.

Environmental factors and metabolic processes are the two main causes of DNA damage. Ionizing radiation has been confirmed as an environmental risk factor for the development of cancer, which can cause DNA damage of different kinds.[6] Base-excision repair (BER), one of DNA repair pathways, mainly repairs single base in damaged DNA molecule. Mutations occurred in BER related genes can lead to change its repair function, and then increases the probability of developing cancer greatly $[7,8]$.

Numerous studies have widely explored the relationship between susceptibility to $\mathrm{BC}$ and single nucleotide polymorphisms (SNPs) in Base-excision repair genes. However, the conclusions remain indecisive as a result of insufficient samples and/or race diversity. These studies include human apurinic/apyrimidinic endonuclease (APE1), x-ray repair cross-complementing 1 (XRCC1), human 8-oxoguanine DNA glycosylase (OGG1, also known as hOGG1), and poly (ADP-ribose) polymerase-1 (ADPAT1, also known as PARP1). Among these, the relationships between risk of $\mathrm{BC}$ and mutations of 
rs25487 and rs1799782 on the XRCC1 gene have caused the greatest controversy among researchers. Positive association between rs25487 mutation [9-14] and the risk of $\mathrm{BC}$ have been reported in single race population studies, but others did not even in the same race [15-21]. Most studies suggest that the rs1799782 mutation is not associated with developing $\mathrm{BC}$, while other studies report it is positively correlated. [9, 11-15, 17, 19] Inconsistent results have also been reported in studies using populations consisting of mixed race. Duell et al. (2001) reported a positive association for rs25487 with BC was found among African Americans but not Caucasian Americans [22]. VIEIRAL et al. (2015) demonstrates genetic background can influence $\mathrm{BC}$ developing, even an inverse association [23].

Meta-analysis is an authoritative way to improve authenticity and provides quantitative pooled values for different races. Previous meta-analysis studies adopted the continental location as the classification standard to discuss the relationship between susceptibility to $\mathrm{BC}$ and SNPs in BER genes [24, 25]. However, there are numerous races distributed on the same continent. For example, the Mongoloid race is mainly located in the East and Southeast of Asia, and the Caucasoid race mainly located in Europe, the Americas, Oceania, North Africa, South and West Asia. Therefore, using human race as the standard of classification to use in stratification analysis may be more appropriate. The purpose of this study is to discuss the relationship between risk of developing BC and BER genes based on genetic ancestry.

\section{MATERIALS AND METHODS}

\section{Literature search strategy}

The Medline, PubMed, Embase, Web of Science were searched (the last search was updated on October 20th 2016) using the search terms "breast cancer", "polymorphism" or "SNP", "DNA Repair Gene" or "base excision DNA repair gene" or "BER gene". All searches were retrieved and their references were checked for other relevant publications. Only published studies with full-text articles were included. When more than one of the same patient populations was included in several studies, only the study with the largest sample size or the complete study was used for this meta-analysis. A flow diagram of the study selection process was shown in Figure 1.

\section{Inclusion and exclusion criteria}

The inclusion and exclusion criteria were established on the basis of discussion and consensus. The inclusion criteria for studies were as follows: (1) casecontrol studies; (2) the aim was to examine the association of the polymorphisms in BER genes with susceptibility of breast cancer; (3) data provided met the requirements of meta-analysis method; (4) genotype distribution in healthy controls complied with the Hardy-Weinberg equilibrium (HWE).

The exclusion criteria were as follows: (1) did not fit the diagnostic criteria; (2) animal study; (3) the aim of the study didn 't focus on susceptibility to breast cancer or not BER genes; (5) genotype distribution healthy controls deviated from the HWE.

\section{Racial classification}

According to the Meyers Konversations-Lexikon (1885-90), human beings can be divided into three major races: Mongoloid race, Caucasoid race, and Negroid race. The Mongoloid race is a term used for all or some people who are indigenous to East Asia, Central Asia, Southeast Asia, North Asia, South Asia, the Arctic, the Americas, the Pacific Islands and other lesser regions, and are the minority group worldwide (https://en.wikipedia.org/ wiki/Mongoloid). The Caucasoid race usually includes some or all of the ancient and modern populations of Europe, the Caucasus, Asia Minor, North Africa, the Horn of Africa, Western Asia, Central Asia and South Asia (https://en.wikipedia.org/wiki/Caucasian_race\#cite_notePickering-8). The Negroid race populations are found in most of Sub-Saharan Africa and isolated parts of Southeast Asia (Negritos) (https://en.wikipedia.org/wiki/Negroid).

The information included in this meta-analysis was arranged and divided into Mongoloid population, Caucasoid population and Negroid population using the criteria above. If the racial origin of the samples could not be clearly defined, the data was assigned to a mixed race group.

\section{Statistical analysis}

A $\chi^{2}$ test was used to determine if observed frequencies of genotypes corresponded to the HWE. Statistical analysis was conducted using $\mathrm{R}$ software and a $P$-value $\leq 0.05$ was considered statistically significant. Dichotomous data was presented as the odds ratio (OR) with a 95\% confidence interval (CI). Statistical heterogeneity was measured using the Q-statistic (P $\leq$ 0.10 was considered to be representative of statistically significant heterogeneity). Effect of heterogeneity quantified by the $I^{2}$ statistic, a fixed effects model was used when there was no heterogeneity in the results of the trials; otherwise, the random effects model was used. Egger's weighted regression method were used to statistically assess the publication bias $(P \leq 0.05$ was considered to indicate statistically significant publication bias). The methods of "Influence analysis" and "Trim and Filled analysis" were both conducted to investigate the sensitivity of the pooled ORs. 


\section{RESULTS}

183 relevant studies with 69 SNPs on 20 BER related genes were retrieved in this research. 114 articles describing 19 genes were excluded from this study due to insufficient publication number (not more than 3 researches). Finally, this study included 69 papers with 33760 BC cases and 33252 controls, and the information was summarized in Table 1. The flow process was shown in Figure 1.

Three SNPs on the XRCC1 gene were analysed in this meta-analysis. As Supplementary Table 1 show, this meta-analysis didn't find any evidence to suggest that mutations in rs25489 and rs1799782 were associated with the susceptibility to develop BC in any race population. But, rs25487 with A allele significantly reduced the risk of developing BC in Mongoloid and Caucasoid populations, but not in the Negroid population (Figures 2 and 3).

Two SNPs on the ADPRT1 gene were analysed in this meta-analysis. As Table 2 shows, there is no evidence which indicates that mutations in SNPs of rs1805414 and rs1136410 were significantly associated with BC. The relationship between two SNPs (rs1130409 and rs1760944) on the APEX1 gene and risk of developing $\mathrm{BC}$ was analysed in this meta-analysis (Figures 4 and 5).

The mutations in rs1130409 did not relate to the risk of developing $B C$, but $T$ mutated to $G$ in rs 1760944 could increase the risk of developing BC in the Mongoloid race. There are insufficient studies which are focused on the relationship of rs1760944 and BC susceptibility outside the Mongoloid population, which restricted the meta-analysis on Mongoloid populations, compared to that done for the Caucasoid and Negroid populations (Table 3 ).

Table 4 shows a CC genotype of rs 1052133 played a protective role in the development of $\mathrm{BC}$ in Mongoloid and Caucasoid race populations (Figures 6, 7 and 8).

Sensitivity analysis demonstrated all the results were robust, and no significant publication bias was found.

\section{DISCUSSION}

This study quantitatively summarized the association between 8 SNPs on 4 BER genes and the risk of developing $\mathrm{BC}$, by pooling the data from 69 papers

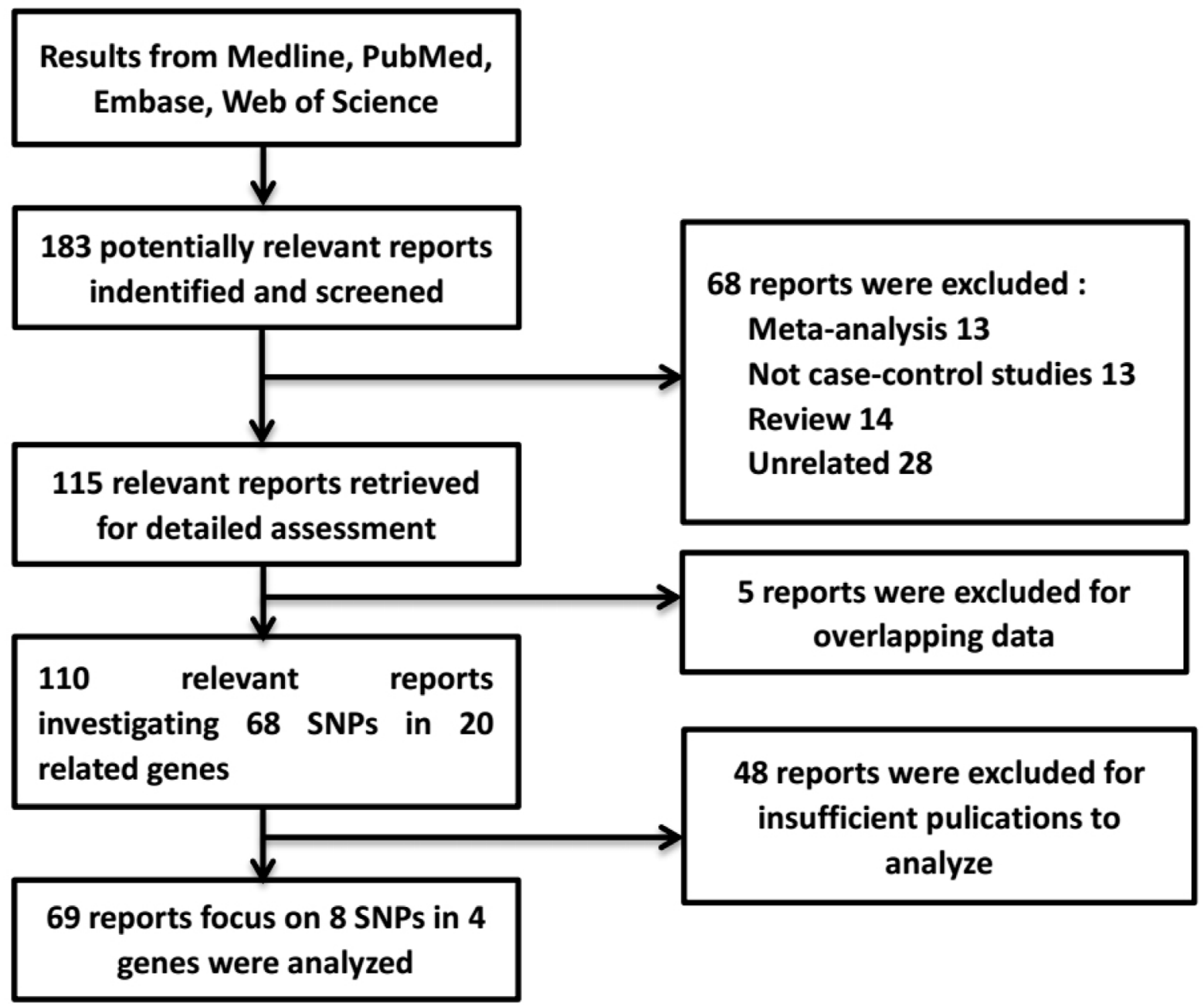

Figure 1: A flow diagram of the studies selection process. 
Table 1: Summary of the SNPs studied in this meta-analysis

\begin{tabular}{|c|c|c|c|c|c|}
\hline $\begin{array}{l}\text { Genes in BER } \\
\text { pathway }\end{array}$ & SNPs & n. of studies included & n. of Cases & n. of Controls & References included \\
\hline \multirow[t]{3}{*}{ XRCC1 } & rs1799782 & 33 & 14991 & 15624 & $\begin{array}{l}{[9,10,12,13,16-23,} \\
26-46]\end{array}$ \\
\hline & rs25487 & 47 & 20995 & 22964 & $\begin{array}{l}{[9-13,15-22,26,27,} \\
29-45,47-60]\end{array}$ \\
\hline & rs25489 & 10 & 7509 & 7403 & $\begin{array}{l}{[16,19,21,28,32,34,} \\
36,43,47,57]\end{array}$ \\
\hline \multirow[t]{2}{*}{ ADPRT1 } & rs 1805414 & 3 & 236 & 269 & [61-63] \\
\hline & rs 1136410 & 7 & 3128 & 2805 & $\begin{array}{l}{[28,32,53,61,62,} \\
64,65]\end{array}$ \\
\hline \multirow[t]{2}{*}{ APEX1 } & rs 1130409 & 12 & 5154 & 5858 & $\begin{array}{l}{[13,14,28,32,35,36,} \\
51,66-70]\end{array}$ \\
\hline & rs1760944 & 4 & 1415 & 1827 & {$[13,14,68,69]$} \\
\hline OGG1 & rs 1052133 & 16 & 11038 & 12799 & $\begin{array}{l}{[14,32,34,36,44,46,} \\
57,67,71-78]\end{array}$ \\
\hline
\end{tabular}

Table 2: Summary about meta-analysis results of SNPs in ADPRT gene and risk of breast cancer

\begin{tabular}{|c|c|c|c|c|c|c|c|c|c|}
\hline \multirow[t]{2}{*}{ SNP } & \multirow{2}{*}{$\begin{array}{l}\text { Genetic } \\
\text { Models }\end{array}$} & \multirow{2}{*}{ Race } & \multirow{2}{*}{$n$} & \multicolumn{3}{|c|}{ OR $(95 \%$ CI) } & \multicolumn{2}{|c|}{ Homogeneity } & \multirow{2}{*}{$\begin{array}{c}P \text { for Publication } \\
\text { Bias test }\end{array}$} \\
\hline & & & & OR & CI & $P$ value & $\mathbf{Q}$ & $I^{2}(\%)$ & \\
\hline \multirow{5}{*}{$\begin{array}{l}\text { Rs1805414 } \\
\text { TT/ CT/ CC }\end{array}$} & $\begin{array}{l}\text { TT + CT vs. CC } \\
\text { (Dominant) }\end{array}$ & Caucasoid & 3 & 0.411 & $0.134-1.256$ & 0.119 & 5.000 & 61.541 & 0.628 \\
\hline & $\begin{array}{l}\text { TT vs. CT + CC } \\
\text { (Recessive) }\end{array}$ & Caucasoid & 3 & 0.576 & $0.195-1.702$ & 0.318 & 17.000 & 88.241 & 0.758 \\
\hline & $\begin{array}{l}\text { T vs. C } \\
\text { (Allele) }\end{array}$ & Caucasoid & 3 & 0.582 & $0.255-1.33$ & 0.200 & 16.000 & 87.383 & 0.332 \\
\hline & $\begin{array}{c}\text { TT vs. CT } \\
\text { (Co-Dominant) }\end{array}$ & Caucasoid & 3 & 0.650 & $0.207-2.038$ & 0.460 & 17.000 & 87.892 & 0.566 \\
\hline & $\begin{array}{c}\text { CT vs. CC } \\
\text { (Co-Dominant) }\end{array}$ & Caucasoid & 3 & 0.519 & $0.169-1.595$ & 0.252 & 5.000 & 57.083 & 0.659 \\
\hline \multirow{10}{*}{ Rs1136410 } & $\mathrm{CT}+\mathrm{CC}$ vs. TT & Overall & 7 & 1.004 & $0.787-1.282$ & 0.971 & 5.000 & 0.000 & 0.188 \\
\hline & (Dominant) & Caucasoid & 6 & 1.075 & $0.776-1.487$ & 0.665 & 4.970 & 0.000 & 0.314 \\
\hline & CC vs. CT+ TT & Overall & 7 & 0.996 & $0.781-1.272$ & 0.971 & 5.000 & 0.000 & 0.683 \\
\hline & (Recessive) & Caucasoid & 6 & 0.931 & $0.672-1.288$ & 0.665 & 4.970 & 0.000 & 0.547 \\
\hline & C vs. T & Overall & 8 & 0.975 & $0.822-1.157$ & 0.772 & 14.000 & 48.680 & 0.147 \\
\hline & (Allele) & Caucasoid & 6 & 0.999 & $0.802-1.247$ & 0.628 & 11.014 & 54.605 & 0.721 \\
\hline & CC vs. CT & Overall & 8 & 0.981 & $0.811-1.186$ & 0.841 & 11.000 & 35.808 & 0.590 \\
\hline & Co-Dominant & Caucasoid & 6 & 1.021 & $0.813-1.283$ & 0.857 & 9.283 & 40.354 & 0.918 \\
\hline & CT vs. TT & Overall & 7 & 1.031 & $0.798-1.331$ & 0.817 & 4.000 & 0.000 & 0.182 \\
\hline & Co-Dominant & Caucasoid & 6 & 1.093 & $0.778-1.534$ & 0.609 & 4.087 & 0.000 & 0.536 \\
\hline
\end{tabular}

with $33760 \mathrm{BC}$ cases and 33252 control individuals. To the best of our knowledge, this paper is novel in its discussion in terms of the difference to the susceptibility to $\mathrm{BC}$ in different races. Overall, the results of this paper found that the mutations of rs25487 on the XRCC1 gene, rs1760944 on APEX1 and rs1052133 on the OGG1 gene were significantly related with susceptibility to BC.
Rs25487 on the XRCC1 gene (also known as Gln399Arg, and A allele encodes the Gln amino acid) was the polymorphism most studied in the risk of cancers. Rs25487 participates in coding of BRCT I domains of XRCC 1, which is one of the interaction domains of BRCA 1 protein [79]. BRCA 1 has been proved to be a predict gene for hereditary $\mathrm{BC}$, it can suppress developing 
Table 3: Summary about meta-analysis results of SNPs in APEX1 gene and risk of breast cancer

\begin{tabular}{|c|c|c|c|c|c|c|c|c|c|}
\hline \multirow[t]{2}{*}{ SNP } & \multirow{2}{*}{$\begin{array}{l}\text { Genetic } \\
\text { Models }\end{array}$} & \multirow{2}{*}{ Race } & \multirow{2}{*}{$n$} & \multicolumn{3}{|c|}{ OR (95\% CI) } & \multicolumn{2}{|c|}{ Homogeneity } & \multirow{2}{*}{$\begin{array}{c}P \text { for } \\
\text { Publication } \\
\text { Bias }\end{array}$} \\
\hline & & & & OR & CI & $P$ value & $Q$ & $I^{2}(\%)$ & \\
\hline \multirow{15}{*}{$\begin{array}{c}\text { Rs1130409 } \\
\text { TT/ TG/ GG }\end{array}$} & \multirow{3}{*}{$\begin{array}{c}\mathrm{TT}+\mathrm{CT} \text { vs. } \\
\mathrm{CC} \\
\text { (Dominant) }\end{array}$} & Overall & 13 & 1.012 & $0.773-1.325$ & 0.932 & 74.000 & 83.730 & 0.412 \\
\hline & & Caucasoid & 7 & 0.942 & $0.604-1.469$ & 0.794 & 60.567 & 90.094 & 0.778 \\
\hline & & Mongoloid & 5 & 1.076 & $0.779-1.486$ & 0.658 & 13.195 & 69.684 & 0.747 \\
\hline & \multirow{3}{*}{$\begin{array}{c}\text { TT vs. } \mathrm{CT}+\mathrm{CC} \\
\text { (Recessive) }\end{array}$} & Overall & 13 & 0.918 & $0.783-1.075$ & 0.288 & 37.000 & 67.181 & 0.703 \\
\hline & & Caucasoid & 7 & 0.840 & $0.623-1.132$ & 0.251 & 30.948 & 80.613 & 0.144 \\
\hline & & Mongoloid & 5 & 0.966 & $0.837-1.115$ & 0.637 & 5.348 & 25.199 & 0.342 \\
\hline & \multirow{3}{*}{$\begin{array}{l}\text { T vs. C } \\
\text { (Allele) }\end{array}$} & Overall & 13 & 0.967 & $0.831-1.124$ & 0.658 & 75.000 & 83.977 & 0.363 \\
\hline & & Caucasoid & 7 & 0.908 & $0.688-1.199$ & $0.4-95$ & 69.148 & 91.323 & 0.786 \\
\hline & & Mongoloid & 5 & 1.005 & $0.903-1.118$ & 0.928 & 5.635 & 29.015 & 0.073 \\
\hline & TT vs. CT & Overall & 13 & 0.878 & $0.753-1.026$ & 0.101 & 30.000 & 60.592 & 0.133 \\
\hline & \multirow[t]{2}{*}{ Co-Dominant } & Caucasoid & 7 & 0.799 & $0.61-1.047$ & 0.104 & 21.625 & 72.254 & 0.739 \\
\hline & & Mongoloid & 5 & 0.937 & $0.775-1.133$ & 0.503 & 8.105 & 50.650 & 0.295 \\
\hline & CT vs. CC & Overall & 13 & 1.074 & $0.812-1.421$ & 0.615 & 69.000 & 82.658 & 0.944 \\
\hline & \multirow[t]{2}{*}{ Co-Dominant } & Caucasoid & 7 & 1.042 & $0.665-1.633$ & 0.858 & 53.503 & 88.786 & 0.978 \\
\hline & & Mongoloid & 5 & 1.111 & $0.764-1.614$ & 0.582 & 15.600 & 74.359 & 0.972 \\
\hline \multirow{10}{*}{$\begin{array}{l}\text { Rs1760944 } \\
\text { TT/ CT /CC }\end{array}$} & \multirow{2}{*}{$\begin{array}{l}\text { TT+CT vs. CC } \\
\text { (Dominant) }\end{array}$} & Overall & 4 & 1.000 & $0.840-1.192$ & 0.996 & 7.000 & 55.865 & 0.899 \\
\hline & & Mongoloid & 3 & 1.021 & $0.854-1.221$ & 0.816 & 5.387 & 62.873 & 0.609 \\
\hline & \multirow{2}{*}{$\begin{array}{c}\text { TT vs. CT+CC } \\
\text { (Recessive) }\end{array}$} & Overall & 4 & 1.265 & $1.086-1.474$ & 0.003 & 4.000 & 23.638 & 0.763 \\
\hline & & Mongoloid & 3 & 1.227 & $1.044-1.441$ & 0.013 & 2.511 & 20.344 & 0.943 \\
\hline & T vs. C & Overall & 4 & 1.106 & $1.001-1.222$ & 0.049 & 6.000 & 50.892 & 0.638 \\
\hline & (Allele) & Mongoloid & 3 & 1.098 & $0.989-1.219$ & 0.081 & 5.909 & 66.153 & 0.609 \\
\hline & TT vs. CT & Overall & 4 & 1.067 & $0.772-1.478$ & 0.122 & 3.000 & 4.848 & 0.359 \\
\hline & Co-Dominant & Mongoloid & 3 & 1.241 & $1.045-1.473$ & 0.014 & 1.201 & 0.000 & 0.727 \\
\hline & CT vs. CC & Overall & 4 & 0.913 & $0.757-1.101$ & 0.337 & 6.000 & 46.736 & 0.882 \\
\hline & Co-Dominant & Mongoloid & 3 & 0.938 & $0.775-1.135$ & 0.511 & 3.641 & 45.072 & 0.279 \\
\hline
\end{tabular}

Table 4: Summary about meta-analysis results of SNPs in OGG1 gene and risk of breast cancer

\begin{tabular}{|c|c|c|c|c|c|c|c|c|c|}
\hline \multirow[t]{2}{*}{ SNP } & \multirow{2}{*}{$\begin{array}{l}\text { Genetic } \\
\text { Models }\end{array}$} & \multirow{2}{*}{ Race } & \multirow{2}{*}{$n$} & \multicolumn{3}{|c|}{ OR(95\% CI) } & \multicolumn{2}{|c|}{ Homogeneity } & \multirow{2}{*}{$\begin{array}{c}P \text { for } \\
\text { Publication } \\
\text { Bias }\end{array}$} \\
\hline & & & & OR & CI & $P$ value & $Q$ & $I^{2}(\%)$ & \\
\hline \multirow{15}{*}{$\begin{array}{l}\text { rs } 1052133 \\
\mathrm{CC} / \mathrm{CG} / \mathrm{GG}\end{array}$} & \multirow{3}{*}{$\begin{array}{l}\text { CC+CG vs. GG } \\
\text { (Dominant) }\end{array}$} & Overall & 20 & 0.767 & $0.611-0.962$ & 0.021 & 128 & 85.21 & 0.478 \\
\hline & & Caucasoid & 11 & 0.646 & $0.376-1.107$ & 0.112 & 111.303 & 91.016 & 0.735 \\
\hline & & Mongoloid & 8 & 0.877 & $0.770-0.998$ & 0.047 & 11.056 & 36.687 & 0.425 \\
\hline & $\mathrm{CC}$ vs $. \mathrm{CG}+\mathrm{GG}$ & Overall & 22 & 1.215 & $0.819-1.802$ & 0.334 & 133 & 84.168 & 0.665 \\
\hline & \multirow[t]{2}{*}{ (Recessive) } & Caucasoid & 13 & 1.224 & $0.962-1.556$ & 0.100 & 112.479 & 89.331 & 0.139 \\
\hline & & Mongoloid & 8 & 0.955 & $0.749-1.217$ & 0.709 & 11.056 & 36.687 & 0.391 \\
\hline & C vs. G & Overall & 20 & 1.002 & $0.897-1.119$ & 0.968 & 115 & 83.47 & 0.841 \\
\hline & \multirow[t]{2}{*}{ (Allele) } & Caucasoid & 11 & 0.994 & $0.818-1.208$ & 0.954 & 87.007 & 88.507 & 0.211 \\
\hline & & Mongoloid & 8 & 1.006 & $0.880-1.149$ & 0.932 & 26.557 & 73.642 & 0.480 \\
\hline & CC vs.CG & Overall & 20 & 0.818 & $0.677-0.987$ & 0.036 & 59 & 67.958 & 0.488 \\
\hline & \multirow[t]{2}{*}{ Co-Dominant } & Caucasoid & 11 & 0.734 & $0.492-1.093$ & 0.128 & 51.521 & 80.591 & 0.577 \\
\hline & & Mongoloid & 8 & 0.855 & $0.749-0.976$ & 0.020 & 7.037 & 0.521 & 0.583 \\
\hline & CG vs. GG & Overall & 20 & 0.752 & $0.595-0.951$ & 0.017 & 122 & 84.455 & 0.289 \\
\hline & \multirow[t]{2}{*}{ Co-Dominant } & Caucasoid & 11 & 0.613 & $0.352-1.070$ & 0.085 & 105.605 & 90.531 & 0.131 \\
\hline & & Mongoloid & 8 & 0.886 & $0.777-1.010$ & 0.052 & 10.097 & 30.673 & 0.735 \\
\hline
\end{tabular}




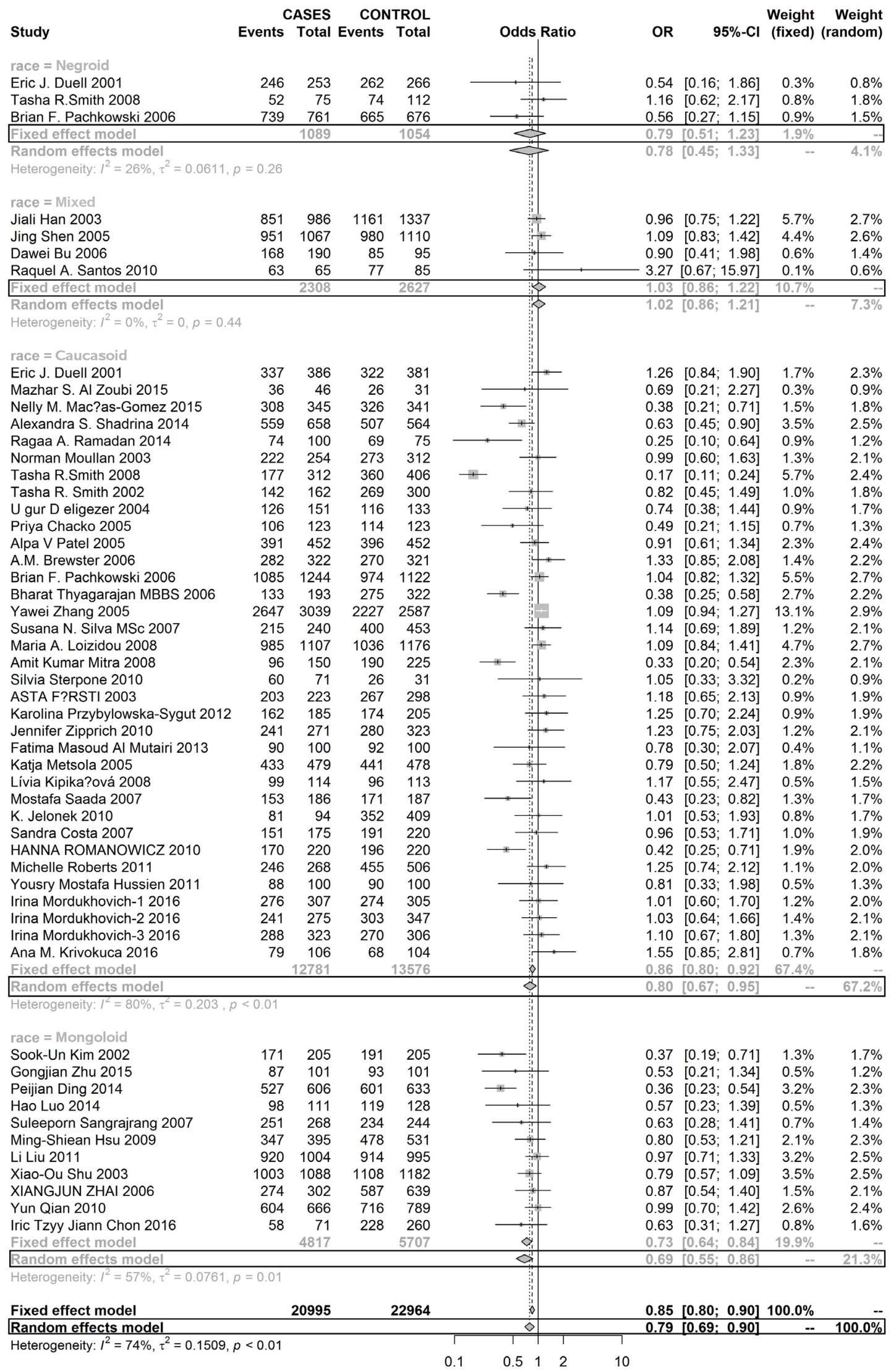

Figure 2: Forest plot of RS25487 polymorphism in XRCC1 and risk to breast cancer (GA+GG vs. AA) (the model adopted was marked by black frame). 
CASES CONTROL

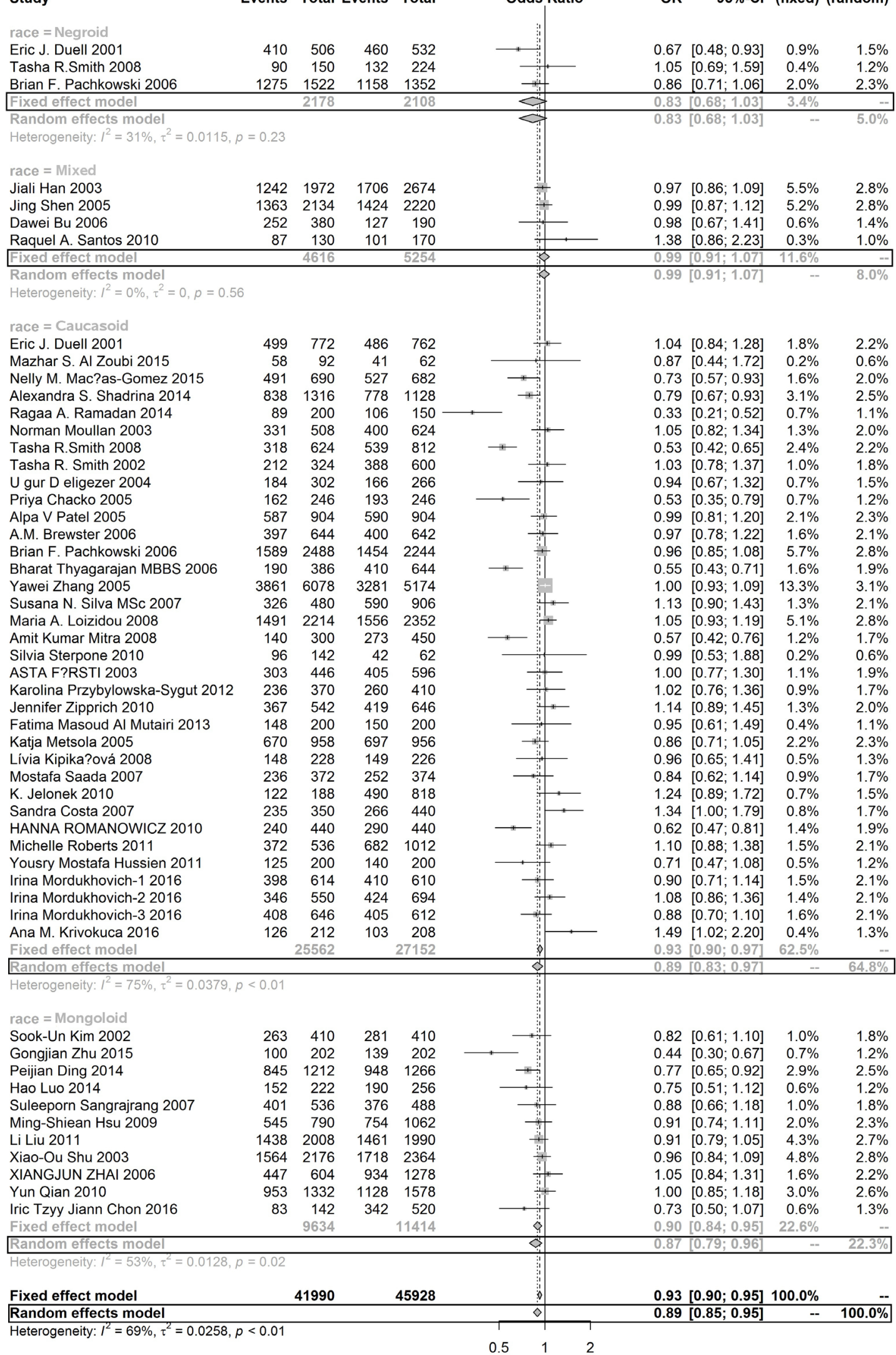

Figure 3: Forest plot of RS25487 polymorphism in XRCC1 and risk to breast cancer (G allele vs. A allele) (the model adopted was marked by black frame). 
of breast cancer in humans $[80,81]$ This meta-analysis found populations with A allele could significantly reduce the risk of developing BC. Similar findings are presented in other cancers studies. For instance, in two studies carried on Americans and Koreans, the rs25487(A/A) genotype significantly reduces the risk of both basal cell and squamous cell cancers [82, 83]. A meta-analysis found the $\mathrm{G}$ allele is one of the risk factors in developing of Glioma in Asians [84]. Another meta-analysis carried out on a Chinese population found XRCC1 Arg399Gln polymorphism is not associated with $\mathrm{BC}$ (at the 5\% level) but indicated a borderline association [85].

In human cells, APE1 gene, located on chromosome 14, encodes the primar AP endonuclease. AP sites is frequently happened in DNA molecules, which can help cells to recognize and repair DNA damage [86]. Rs 1130409 and rs 1760944 on the APE1 gene has been widely researched with respect to its role in cancer susceptibility [87-89]. By pooling 4 studies (3 on Chinese populations and 1 on an Iran population),

Study
Events Total Events Total

Figure 4: Forest plot of rs1760944 polymorphism in APEX1 and risk to breast cancer (TT vs. CT) (the model adopted was marked by black frame).

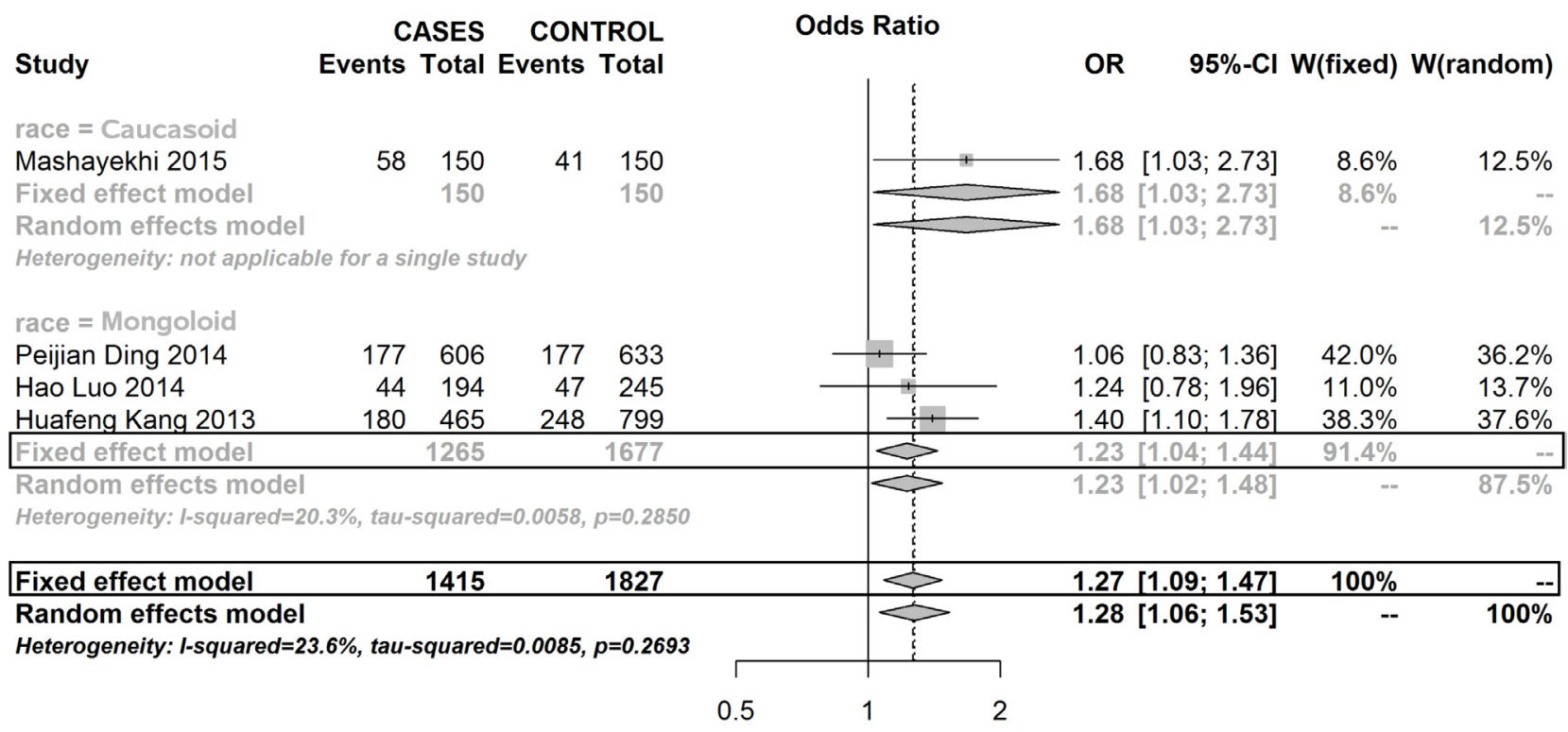

Figure 5: Forest plot of rs1760944 polymorphism in APEX1 and risk to breast cancer (TT vs. CT+CC) (the model adopted was marked by black frame). 


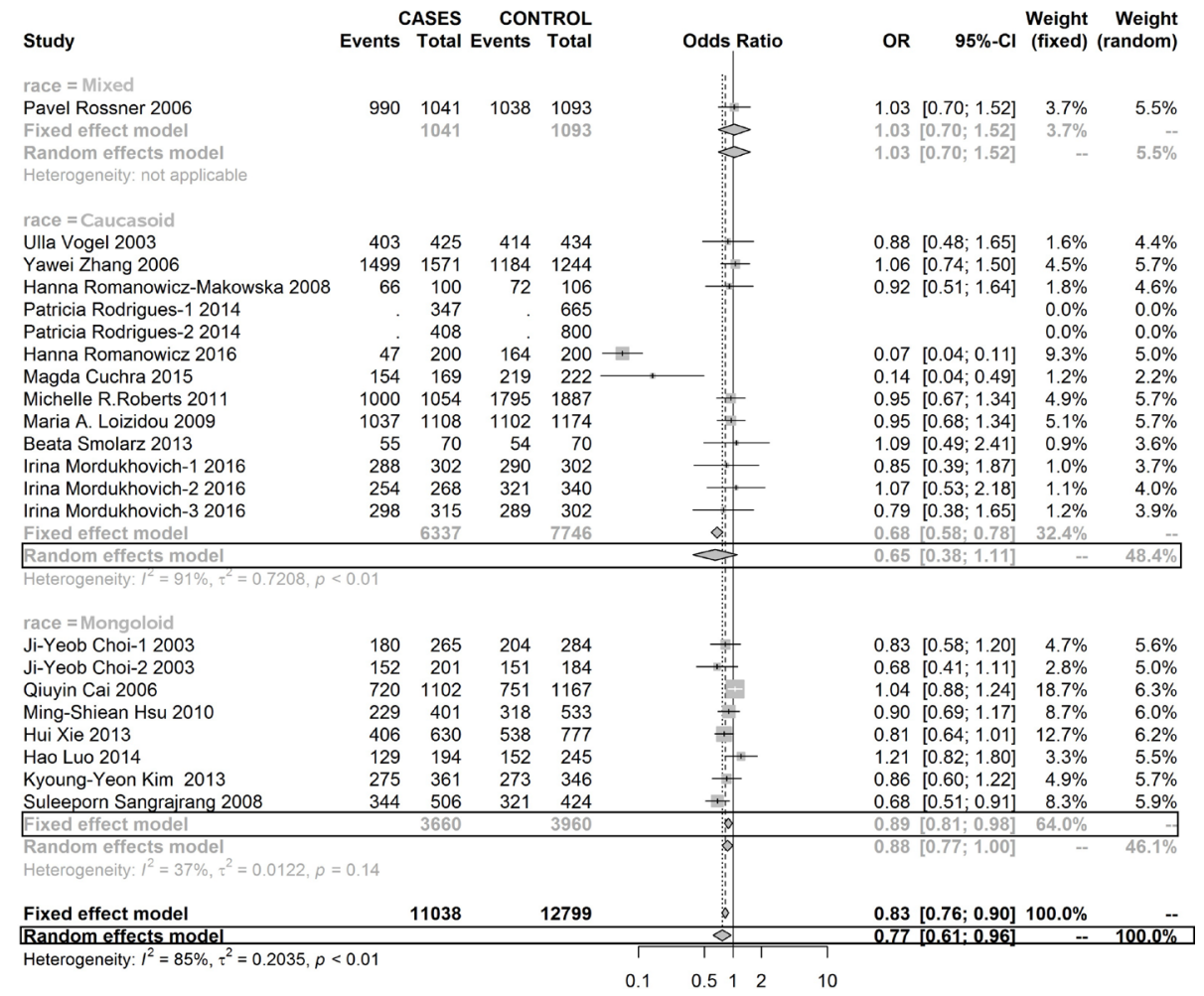

Figure 6: Forest plot of rs1052133 polymorphism in OGG1 and risk to breast cancer (CC+CG vs. GG) (the model adopted was marked by black frame).

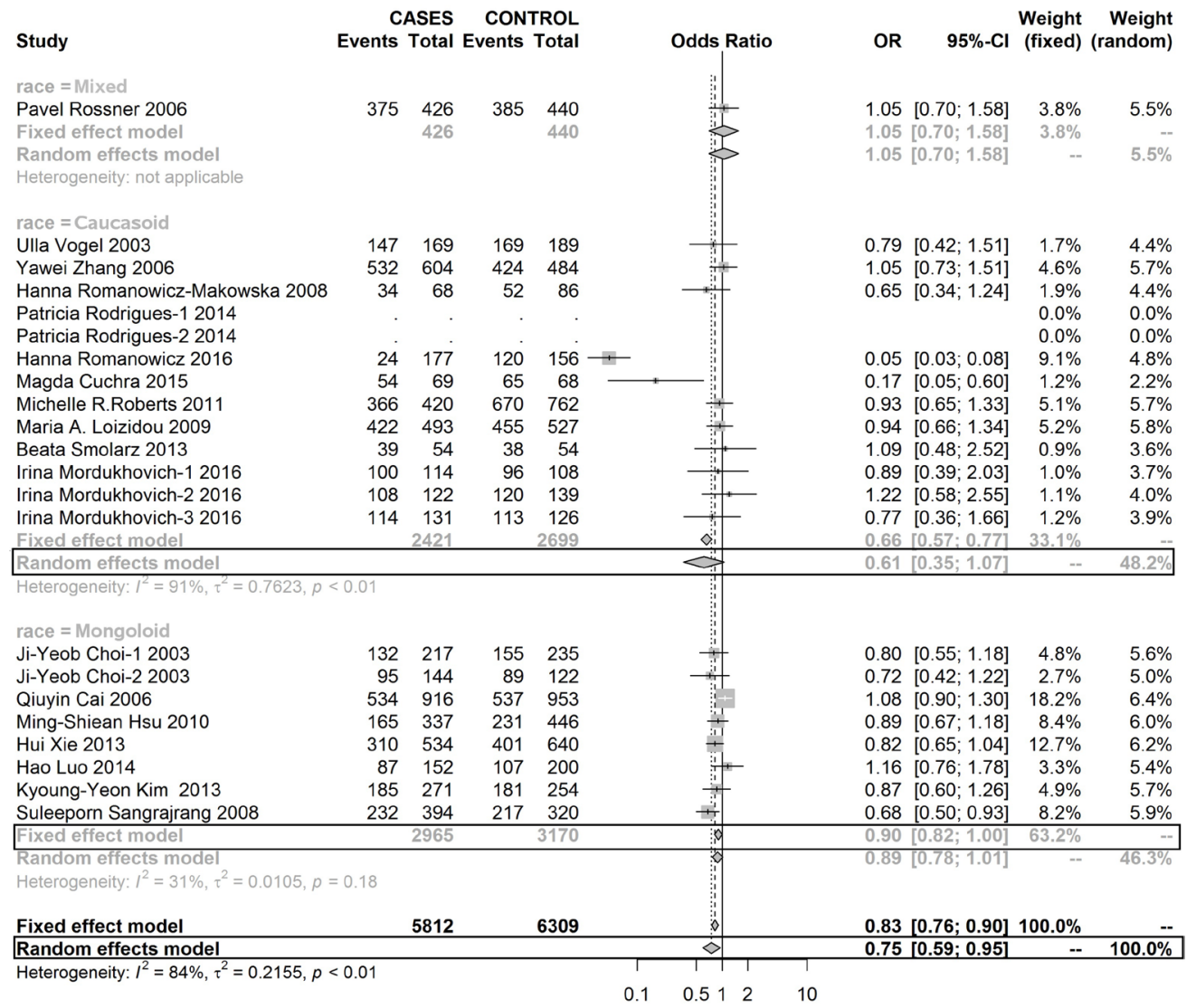

Figure 7: Forest plot of rs1052133 polymorphism in OGG1 and thus risk to breast cancer (CG vs. GG) (the model adopted was marked by black frame). 
this meta-analysis found the rs1760944 (also known as $-656 \mathrm{~T}>\mathrm{G}$ ) variants was associated with an incaresed risk of developing $\mathrm{BC}$ in Mongoloid populations, or more specifically, in the Chinese population. Rs 1760944 polymorphism is located on Polymorphisms in a promoter region and is located -141bp upstream from the transcription initiation site. Variants in the promoter region, or 3'UTR, of a gene may influence its function and lead to abnormal protein expression. Function studies have proved that Rs1760944 mutation can influence its activity of communicating to other BER proteins [69].

The key role of OGG1 protein is to cleave 8-hydroxyguanine. [90] Rs1052133, also known as Ser326Cys, is a SNP on the OGG1 gene, and the minor (G) allele, encoding the cysteine. This paper found that in contrast to the GG genotype, people who carried the $\mathrm{CC}$ or $\mathrm{CG}$ genotype had a lower risk of developing $\mathrm{BC}$ in both the Mongoloid and Caucasoid race populations. This study indicated that $\mathrm{rs} 1052133$ may follow a recessive inheritance pattern in BC susceptibility, because the OR of $\mathrm{CC}$ vs. GG genotypes was similar to CG vs. GG genotypes (results shown in Table 4). Lee et al. (2015) found that ability of oxidative DNA damage repair was significant lower in GG genotype individuals than non-GG genotype individuals [91].

\section{CONCLUSIONS}

This study suggests that rs1052133, rs25487 and rs1760944 polymorphisms may influence individual susceptibility to risk of developing $\mathrm{BC}$, and provides evidence which supports the idea that mutations of the DNA repair genes are associated to $\mathrm{BC}$ risk. The understanding of $\mathrm{BC}$ etiology and roles in the potential biological pathways linking DNA repair, ethnic background, environment and BC need to be studied further.

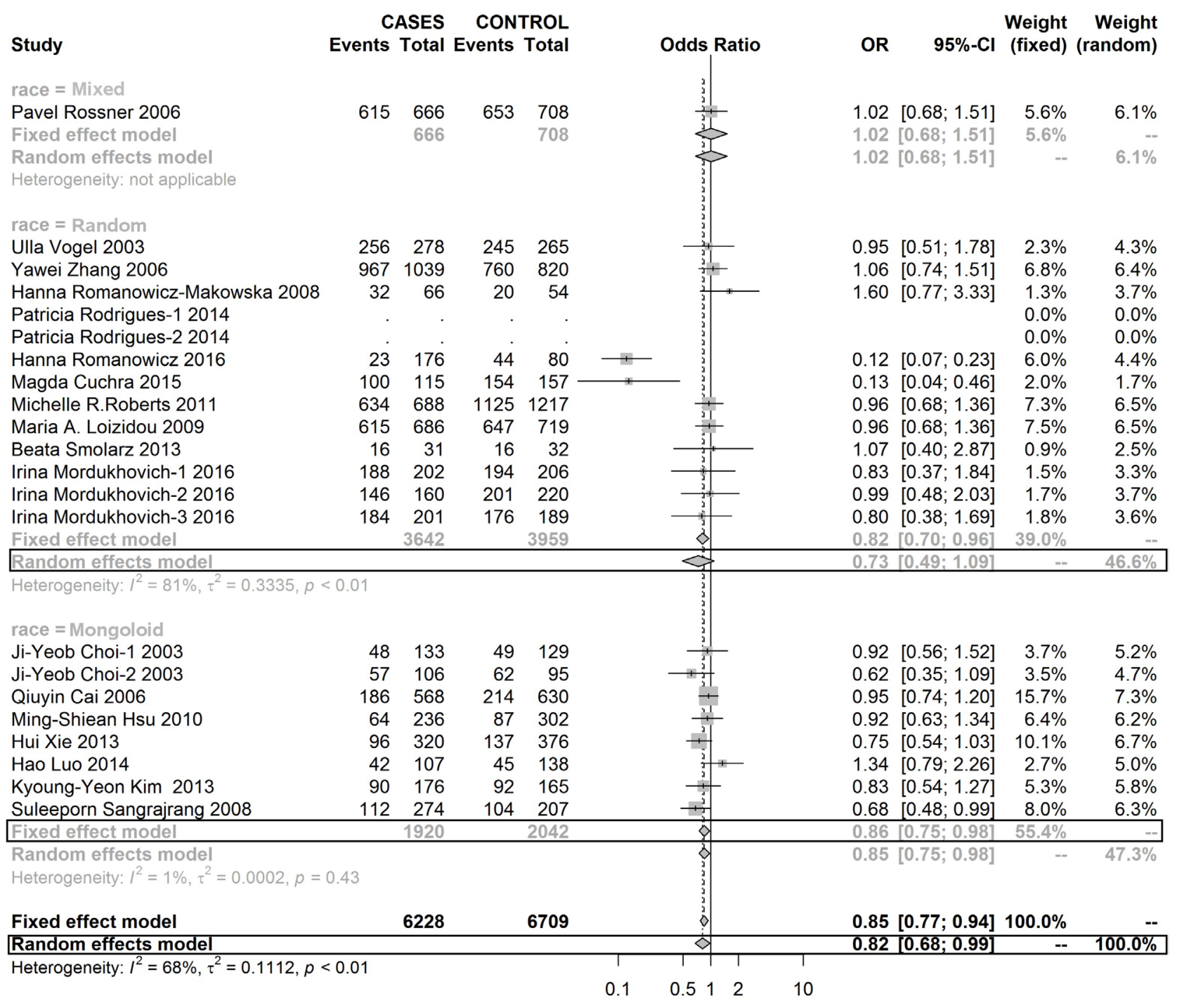

Figure 8: Forest plot of rs1052133 polymorphism in OGG1 and thus risk to breast cancer (CC vs. GG) (the model adopted was marked by black frame). 


\section{CONFLICTS OF INTEREST}

The authors state that there are no conflicts of interest to disclose.

\section{REFERENCES}

1. McGuire A, Brown JA, Malone C, McLaughlin R, Kerin MJ. Effects of age on the detection and management of breast cancer. Cancers (Basel). 2015; 7:908-929.

2. Anothaisintawee $\mathrm{T}$, Wiratkapun $\mathrm{C}$, Lerdsitthichai $\mathrm{P}$, Kasamesup V, Wongwaisayawan S, Srinakarin J, Hirunpat S, Woodtichartpreecha P, Boonlikit S, Teerawattananon Y, Thakkinstian A. Risk factors of breast cancer: a systematic review and meta-analysis. Asia Pac J Public Health. 2013; 25:368-387.

3. Pharoah PD, Antoniou A, Bobrow M, Zimmern RL, Easton DF, Ponder BA. Polygenic susceptibility to breast cancer and implications for prevention. Nat Genet. 2002; 31:3336.

4. Colditz GA, Kaphingst KA, Hankinson SE, Rosner B. Family history and risk of breast cancer: nurses' health study. Breast Cancer Res Treat. 2012; 133:1097-1104.

5. Collaborative Group on Hormonal Factors in Breast Cancer. Familial breast cancer: collaborative reanalysis of individual data from 52 epidemiological studies including 58,209 women with breast cancer and 101,986 women without the disease. Lancet. 2001; 358:1389-1399.

6. Shevtsov MA, Nikolaev BP, Ryzhov VA, Yakovleva LY, Marchenko YY, Parr MA, Rolich VI, Mikhrina AL, Dobrodumov AV, Pitkin E, Multhoff G. Ionizing radiation improves glioma-specific targeting of superparamagnetic iron oxide nanoparticles conjugated with cmHsp70.1 monoclonal antibodies (SPION-cmHsp70.1). Nanoscale. 2015; 7:20652-20664.

7. Starcevic D, Dalal S, Sweasy JB. Is there a link between DNA polymerase beta and cancer? Cell Cycle. 2004; 3:998-1001.

8. Farrington SM, Tenesa A, Barnetson R, Wiltshire A, Prendergast J, Porteous M, Campbell H, Dunlop MG. Germline susceptibility to colorectal cancer due to baseexcision repair gene defects. Am J Hum Genet. 2005; 77:112-119.

9. Kim SU, Park SK, Yoo KY, Yoon KS, Choi JY, Seo JS, Park WY, Kim JH, Noh DY, Ahn SH, Choe KJ, Strickland PT, Hirvonen A, Kang D. XRCC1 genetic polymorphism and breast cancer risk. Pharmacogenetics. 2002; 12:335-338.

10. Zhu G, Wang L, Guo H, Lu L, Yang S, Wang T, Guo H, Wang H, Min J, Yang K, Chen X, Liu Y, Wang Z, Su H. DNA repair genes XRCC1 and ERCC1 polymorphisms and the risk of sporadic breast cancer in Han women in the Gansu Province of China. Genet Test Mol Biomarkers. 2015; 19:387-393.

11. Shadrina AS, Ermolenko NA, Boyarskikh UA, Sinkina TV, Lazarev AF, Petrova VD, Filipenko ML. Polymorphisms in DNA repair genes and breast cancer risk in Russian population: a case-control study. Clin Exp Med. 2016; 16:21-28.

12. Ramadan RA, Desouky LM, Elnaggar MA, Moaaz M, Elsherif AM. Association of DNA Repair Genes XRCC1 (Arg399Gln), (Arg194Trp) and XRCC3 (Thr241Met) Polymorphisms with the Risk of Breast Cancer: A CaseControl Study in Egypt. Genet Test Mol Biomarkers. 2014; 18:754-760.

13. Ding P, Yang Y, Cheng L, Zhang X, Cheng L, Li C, Cai J. The relationship between seven common polymorphisms from five DNA repair genes and the risk for breast cancer in northern Chinese women. PLoS One. 2014; 9:e92083.

14. Luo H, Li Z, Qing Y, Zhang SH, Peng Y, Li Q, Wang D. Single nucleotide polymorphisms of DNA base-excision repair genes (APE1, OGG1 and XRCC1) associated with breast cancer risk in a Chinese population. Asian Pac J Cancer Prev. 2014; 15:1133-1140.

15. Al Zoubi MS. X-ray repair cross-complementing protein 1 and 3 polymorphisms and susceptibility of breast cancer in a Jordanian population. Saudi Med J. 2015; 36:1163-1167.

16. Moullan N, Cox DG, Angele S, Romestaing P, Gerard JP, Hall J. Polymorphisms in the DNA repair gene XRCC1, breast cancer risk, and response to radiotherapy. Cancer Epidemiol Biomarkers Prev. 2003; 12:1168-1174.

17. Smith TR, Miller MS, Lohman K, Lange EM, Case LD, Mohrenweiser HW, Hu JJ. Polymorphisms of XRCC1 and XRCC3 genes and susceptibility to breast cancer. Cancer Lett. 2003; 190:183-190.

18. Deligezer U, Dalay N. Association of the XRCC1 gene polymorphisms with cancer risk in Turkish breast cancer patients. Exp Mol Med. 2004; 36:572-575.

19. Chacko P, Rajan B, Joseph T, Mathew BS, Pillai MR. Polymorphisms in DNA repair gene XRCC1 and increased genetic susceptibility to breast cancer. Breast Cancer Res Treat. 2005; 89:15-21.

20. Shen J, Gammon MD, Terry MB, Wang L, Wang Q, Zhang F, Teitelbaum SL, Eng SM, Sagiv SK, Gaudet MM, Neugut AI, Santella RM. Polymorphisms in XRCC1 modify the association between polycyclic aromatic hydrocarbon-DNA adducts, cigarette smoking, dietary antioxidants, and breast cancer risk. Cancer Epidemiol Biomarkers Prev. 2005; 14:336-342.

21. Pachkowski BF, Winkel S, Kubota Y, Swenberg JA, Millikan RC, Nakamura J. XRCC1 genotype and breast cancer: functional studies and epidemiologic data show interactions between XRCC1 codon 280 His and smoking. Cancer Res. 2006; 66:2860-2868.

22. Duell EJ, Millikan RC, Pittman GS, Winkel S, Lunn RM, Tse CK, Eaton A, Mohrenweiser HW, Newman B, Bell DA. Polymorphisms in the DNA repair gene XRCC1 and breast cancer. Cancer Epidemiol Biomarkers Prev. 2001; 10:217222.

23. Vieira PC, Burbano RM, Fernandes DC, Montenegro RC, Dos Santos SE, Sortica VA, Assumpcao PP, Ribeiro-Dos- 
Santos AK, Carvalho AA, Dos Santos NP. Population stratification effect on cancer susceptibility in an admixed population from Brazilian Amazon. Anticancer Res. 2015; 35:2009-2014.

24. Zhao Z, Liu C, Zeng Y, Gu L, Ying M, Wang N, Hao B, Yao $\mathrm{H}, \mathrm{Su} \mathrm{C}$, Wang Y, Ma Y. The association between the APE1 Asp148Glu polymorphism and breast cancer susceptibility: a meta-analysis based on case-control studies. Tumour Biol. 2014; 35:4727-4734.

25. Wu B, Liu HL, Zhang S, Dong XR, Wu G. Lack of an association between two BER gene polymorphisms and breast cancer risk: a meta-analysis. PLoS One. 2012; 7:e50857.

26. Macias-Gomez NM, Peralta-Leal V, Meza-Espinoza JP, Gutierrez-Angulo M, Duran-Gonzalez J, Ramirez-Gonzalez JM, Gaspar-Del Toro A, Norberto-Rodriguez A, LealUgarte E. Polymorphisms of the XRCC1 gene and breast cancer risk in the Mexican population. Fam Cancer. 2015; 14:349-354.

27. Han J, Hankinson SE, De Vivo I, Spiegelman D, Tamimi RM, Mohrenweiser HW, Colditz GA, Hunter DJ. A prospective study of XRCC1 haplotypes and their interaction with plasma carotenoids on breast cancer risk. Cancer Res. 2003; 63:8536-8541.

28. Smith TR, Levine EA, Freimanis RI, Akman SA, Allen GO, Hoang KN, Liu-Mares W, Hu JJ. Polygenic model of DNA repair genetic polymorphisms in human breast cancer risk. Carcinogenesis. 2008; 29:2132-2138.

29. Patel AV, Calle EE, Pavluck AL, Feigelson HS, Thun MJ, Rodriguez C. A prospective study of XRCC1 (X-ray crosscomplementing group 1) polymorphisms and breast cancer risk. Breast Cancer Res. 2005; 7:R1168-1173.

30. Brewster AM, Jorgensen TJ, Ruczinski I, Huang HY, Hoffman S, Thuita L, Newschaffer C, Lunn RM, Bell D, Helzlsouer KJ. Polymorphisms of the DNA repair genes XPD (Lys751Gln) and XRCC1 (Arg399Gln and Arg194Trp): relationship to breast cancer risk and familial predisposition to breast cancer. Breast Cancer Res Treat. 2006; 95:73-80.

31. Thyagarajan B, Anderson KE, Folsom AR, Jacobs DR Jr, Lynch CF, Bargaje A, Khaliq W, Gross MD. No association between XRCC1 and XRCC3 gene polymorphisms and breast cancer risk: Iowa Women's Health Study. Cancer Detect Prev. 2006; 30:313-321.

32. Zhang Y, Newcomb PA, Egan KM, Titus-Ernstoff L, Chanock S, Welch R, Brinton LA, Lissowska J, BardinMikolajczak A, Peplonska B, Szeszenia-Dabrowska N, Zatonski W, Garcia-Closas M. Genetic polymorphisms in base-excision repair pathway genes and risk of breast cancer. Cancer Epidemiol Biomarkers Prev. 2006; 15:353-358.

33. Silva SN, Moita R, Azevedo AP, Gouveia R, Manita I, Pina JE, Rueff J, Gaspar J. Menopausal age and XRCC1 gene polymorphisms: role in breast cancer risk. Cancer Detect Prev. 2007; 31:303-309.
34. Loizidou MA, Michael T, Neuhausen SL, Newbold RF, Marcou Y, Kakouri E, Daniel M, Papadopoulos P, Malas S, Kyriacou K, Hadjisavvas A. Genetic polymorphisms in the DNA repair genes XRCC1, XRCC2 and XRCC3 and risk of breast cancer in Cyprus. Breast Cancer Res Treat. 2008; 112:575-579.

35. Mitra AK, Singh N, Singh A, Garg VK, Agarwal A, Sharma M, Chaturvedi R, Rath SK. Association of polymorphisms in base excision repair genes with the risk of breast cancer: a case-control study in North Indian women. Oncol Res. 2008; 17:127-135.

36. Sangrajrang S, Schmezer P, Burkholder I, Waas P, Boffetta P, Brennan P, Bartsch H, Wiangnon S, Popanda O. Polymorphisms in three base excision repair genes and breast cancer risk in Thai women. Breast Cancer Res Treat. 2008; 111:279-288.

37. Ming-Shiean H, Yu JC, Wang HW, Chen ST, Hsiung CN, Ding SL, Wu PE, Shen CY, Cheng CW. Synergistic effects of polymorphisms in DNA repair genes and endogenous estrogen exposure on female breast cancer risk. Ann Surg Oncol. 2010; 17:760-771.

38. Sterpone S, Mastellone V, Padua L, Novelli F, Patrono C, Cornetta T, Giammarino D, Donato V, Testa A, Cozzi R. Single-nucleotide polymorphisms in BER, HRR genes, XRCC1 haplotypes and breast cancer risk in Caucasian women. J Cancer Res Clin Oncol. 2010; 136:631-636.

39. Forsti A, Angelini S, Festa F, Sanyal S, Zhang Z, Grzybowska E, Pamula J, Pekala W, Zientek H, Hemminki K, Kumar R. Single nucleotide polymorphisms in breast cancer. Oncol Rep. 2004; 11:917-922.

40. Przybylowska-Sygut K, Stanczyk M, Kusinska R, Kordek R, Majsterek I. Association of the Arg194Trp and the Arg399Gln polymorphisms of the XRCC1 gene with risk occurrence and the response to adjuvant therapy among Polish women with breast cancer. Clin Breast Cancer. 2013; 13:61-68.

41. Zipprich J, Terry MB, Brandt-Rauf P, Freyer GA, Liao Y, Agrawal M, Gurvich I, Senie R, Santella RM. XRCC1 polymorphisms and breast cancer risk from the New York Site of the Breast Cancer Family Registry: A family-based case-control study. J Carcinog. 2010; 9:4.

42. Al Mutairi FM, Alanazi M, Shalaby M, Alabdulkarim HA, Pathan AA, Parine NR. Association of XRCC1 gene polymorphisms with breast cancer susceptibility in Saudi patients. Asian Pac J Cancer Prev. 2013; 14:3809-3813.

43. Liu L, Yuan P, Liu L, Wu C, Zhang X, Guo H, Zhong R, Xu Y, Wu J, Duan S, Rui R, Wu T, Nie S, et al. A functional $-77 \mathrm{~T}>\mathrm{C}$ polymorphism in $\mathrm{XRCC} 1$ is associated with risk of breast cancer. Breast Cancer Res Treat. 2011; 125:479-487.

44. Mordukhovich I, Beyea J, Herring AH, Hatch M, Stellman SD, Teitelbaum SL, Richardson DB, Millikan RC, Engel LS, Shantakumar S, Steck SE, Neugut AI, Rossner P Jr, et al. Polymorphisms in DNA repair genes, traffic-related polycyclic aromatic hydrocarbon exposure and breast cancer incidence. Int J Cancer. 2016; 139:310-321. 
45. Chong ET, Goh LP, See EU, Chuah JA, Chua KH, Lee PC. Association of CYP2E1, STK15 and XRCC1 Polymorphisms with Risk of Breast Cancer in Malaysian Women. Asian Pac J Cancer Prev. 2016; 17:647-653.

46. Smolarz B, Makowska M, Samulak D, Michalska MM, Mojs E, Wilczak M, Romanowicz H. Single nucleotide polymorphisms (SNPs) of ERCC2, hOGG1, and XRCC1 DNA repair genes and the risk of triple-negative breast cancer in Polish women. Tumour Biol. 2014; 35:3495-3502.

47. Metsola K, Kataja V, Sillanpaa P, Siivola P, Heikinheimo L, Eskelinen M, Kosma VM, Uusitupa M, Hirvonen A. XRCC1 and XPD genetic polymorphisms, smoking and breast cancer risk in a Finnish case-control study. Breast Cancer Res. 2005; 7:R987-997.

48. Shu XO, Cai Q, Gao YT, Wen W, Jin F, Zheng W. A population-based case-control study of the Arg399Gln polymorphism in DNA repair gene XRCC1 and risk of breast cancer. Cancer Epidemiol Biomarkers Prev. 2003; 12:1462-1467.

49. Ali MF, Meza JL, Rogan EG, Chakravarti D. Prevalence of BER gene polymorphisms in sporadic breast cancer. Oncol Rep. 2008; 19:1033-1038.

50. Kipikasova L, Wolaschka T, Bohus P, Baumohlova H, Bober J, Blazejova J, Mirossay L, Sarissky M, Mirossay A, Cizmarikova M, Potocekova D, Mojzis J. Polymorphisms of the XRCC1 and XPD genes and breast cancer risk: a case-control study. Pathol Oncol Res. 2008; 14:131-135.

51. Jelonek K, Gdowicz-Klosok A, Pietrowska M, Borkowska M, Korfanty J, Rzeszowska-Wolny J, Widlak P. Association between single-nucleotide polymorphisms of selected genes involved in the response to DNA damage and risk of colon, head and neck, and breast cancers in a Polish population. J Appl Genet. 2010; 51:343-352.

52. Saadat M, Kohan L, Omidvari S. Genetic polymorphisms of XRCC1 (codon 399) and susceptibility to breast cancer in Iranian women, a case-control study. Breast Cancer Res Treat. 2008; 111:549-553.

53. Zhai X, Liu J, Hu Z, Wang S, Qing J, Wang X, Jin G, Gao J, Wang X, Shen H. Polymorphisms of ADPRT Val762Ala and XRCC1 Arg399Glu and risk of breast cancer in Chinese women: a case control analysis. Oncol Rep. 2006; 15:247252 .

54. Costa S, Pinto D, Pereira D, Rodrigues H, CameselleTeijeiro J, Medeiros R, Schmitt F. DNA repair polymorphisms might contribute differentially on familial and sporadic breast cancer susceptibility: a study on a Portuguese population. Breast Cancer Res Treat. 2007; 103:209-217.

55. Romanowicz H, Smolarz B, Baszczynski J, Zadrozny M, Kulig A. Genetics polymorphism in DNA repair genes by base excision repair pathway (XRCC1) and homologous recombination (XRCC2 and RAD51) and the risk of breast carcinoma in the Polish population. Pol J Pathol. 2010; 61:206-212.
56. Santos RA, Teixeira AC, Mayorano MB, Carrara HH, Andrade JM, Takahashi CS. DNA repair genes XRCC1 and XRCC3 polymorphisms and their relationship with the level of micronuclei in breast cancer patients. Genet Mol Biol. 2010; 33:637-640.

57. Roberts MR, Shields PG, Ambrosone CB, Nie J, Marian C, Krishnan SS, Goerlitz DS, Modali R, Seddon M, Lehman T, Amend KL, Trevisan M, Edge SB, Freudenheim JL. Single-nucleotide polymorphisms in DNA repair genes and association with breast cancer risk in the web study. Carcinogenesis. 2011; 32:1223-1230.

58. Sapkota Y, Mackey JR, Lai R, Franco-Villalobos C, Lupichuk S, Robson PJ, Kopciuk K, Cass CE, Yasui Y, Damaraju S. Assessing SNP-SNP interactions among DNA repair, modification and metabolism related pathway genes in breast cancer susceptibility. PLoS One. 2013; 8:e64896.

59. Qian Y, Zhang JP, Dong J, Wang FR, Lin YD, Xu M, Wu LL, Shi P, Shen HB. [Relationship between polymorphisms of X-ray repair cross-complementing group 1 gene Arg194Trp, Arg399Gln and susceptibility of breast cancer]. [Article in Chinese]. Zhonghua Yu Fang Yi Xue Za Zhi. 2010; 44:242-46.

60. Krivokuca AM, Cavic MR, Malisic EJ, Rakobradovic JD, Kolarevic-Ivankovic D, Tomasevic ZI, Brankovic-Magic MV. Polymorphisms in cancer susceptibility genes XRCC1, RAD51 and TP53 and the risk of breast cancer in Serbian women. Int J Biol Markers. 2016; 31:e258-263.

61. Durocher F, Labrie Y, Ouellette G, Simard J, and INHERIT BRCAs. Genetic sequence variations and ADPRT haplotype analysis in French Canadian families with high risk of breast cancer. J Hum Genet. 2007; 52:963-977.

62. Cao WH, Wang X, Frappart L, Rigal D, Wang ZQ, Shen Y, Tong WM. Analysis of genetic variants of the poly(ADPribose) polymerase-1 gene in breast cancer in French patients. Mutat Res. 2007; 632:20-28.

63. Alanazi M, Pathan AA, Shaik JP, Amri AA, Parine NR. The C allele of a synonymous SNP (rs1805414, Ala284Ala) in PARP1 is a risk factor for susceptibility to breast cancer in Saudi patients. Asian Pac J Cancer Prev. 2013; 14:3051-3056.

64. Alanazi M, Pathan AA, Abduljaleel Z, Shaik JP, Alabdulkarim HA, Semlali A, Bazzi MD, Parine NR. Association between PARP-1 V762A polymorphism and breast cancer susceptibility in Saudi population. PLoS One. 2013; 8:e85541.

65. Smolarz B, Makowska M, Samulak D, Michalska MM, Mojs E, Wilczak M, Romanowicz H. Association between single nucleotide polymorphisms (SNPs) of XRCC2 and $\mathrm{XRCC} 3$ homologous recombination repair genes and triplenegative breast cancer in Polish women. Clin Exp Med. 2015; 15:151-157.

66. AlMutairi F, Pathan AA, Alanazi M, Shalaby M, Alabdulkarim HA, Alamri A, Al Naeem A, Elrobh M, Shaik JP, Khan W, Khan Z, Parine NR. Association of DNA Repair Gene APE1 Asp148Glu Polymorphism with Breast Cancer Risk. Dis Markers. 2015; 2015:869512. 
67. Kim KY, Han W, Noh DY, Kang D, Kwack K. Impact of genetic polymorphisms in base excision repair genes on the risk of breast cancer in a Korean population. Gene. 2013; 532:192-196.

68. Kang H, Dai Z, Ma X, Ma L, Jin Y, Liu X, Wang X. A genetic variant in the promoter of APE1 gene $(-656 \mathrm{~T}>\mathrm{G})$ is associated with breast cancer risk and progression in a Chinese population. Gene. 2013; 531:97-100.

69. Mashayekhi F, Yousefi M, Salehi Z, Saedi HS, Pournourali M. The association of ApE1 $-656 \mathrm{~T}>\mathrm{G}$ and $1349 \mathrm{~T}>\mathrm{G}$ polymorphisms with breast cancer susceptibility in northern Iran. Cell Mol Biol (Noisy-le-grand). 2015; 61:70-74.

70. Grundy A, Richardson H, Schuetz JM, Burstyn I, Spinelli JJ, Brooks-Wilson A, Aronson KJ. DNA repair variants and breast cancer risk. Environ Mol Mutagen. 2016; 57:269-281.

71. Choi JY, Hamajima N, Tajima K, Yoo KY, Yoon KS, Park SK, Kim SU, Lee KM, Noh DY, Ahn SH, Choe KJ, Han W, Hirvonen A, Kang D. hOGG1 Ser326Cys polymorphism and breast cancer risk among Asian women. Breast Cancer Res Treat. 2003; 79:59-62.

72. Rossner P Jr, Terry MB, Gammon MD, Zhang FF, Teitelbaum SL, Eng SM, Sagiv SK, Gaudet MM, Neugut AI, Santella RM. OGG1 polymorphisms and breast cancer risk. Cancer Epidemiol Biomarkers Prev. 2006; 15:811-815.

73. Vogel U, Nexo BA, Olsen A, Thomsen B, Jacobsen NR, Wallin H, Overvad K, Tjonneland A. No association between OGG1 Ser326Cys polymorphism and breast cancer risk. Cancer Epidemiol Biomarkers Prev. 2003; 12:170-171.

74. Cai Q, Shu XO, Wen W, Courtney R, Dai Q, Gao YT, Zheng W. Functional Ser326Cys polymorphism in the hOGG1 gene is not associated with breast cancer risk. Cancer Epidemiol Biomarkers Prev. 2006; 15:403-404.

75. Xie H, Xia K, Rong H, Chen X. Genetic polymorphism in hOGG1 is associated with triple-negative breast cancer risk in Chinese Han women. Breast. 2013; 22:707-712.

76. Rodrigues P, de Marco G, Furriol J, Mansego ML, PinedaAlonso M, Gonzalez-Neira A, Martin-Escudero JC, Benitez J, Lluch A, Chaves FJ, Eroles P. Oxidative stress in susceptibility to breast cancer: study in Spanish population. BMC Cancer. 2014; 14:861.

77. Romanowicz H, Pyziak L, Jablonski F, Brys M, Forma E, Smolarz B. Analysis of DNA Repair Genes Polymorphisms in Breast Cancer. Pathol Oncol Res. 2017; 23:117-23.

78. Cuchra M, Mucha B, Markiewicz L, Przybylowska-Sygut K, Pytel D, Jeziorski A, Kordek R, Majsterek I. The role of base excision repair in pathogenesis of breast cancer in the Polish population. Mol Carcinog. 2016; 55:1899-1914.

79. Taylor RM, Thistlethwaite A, Caldecott KW. Central role for the XRCC1 BRCT I domain in mammalian DNA singlestrand break repair. Mol Cell Biol. 2002; 22:2556-2563.

80. Duncan JA, Reeves JR, Cooke TG. BRCA1 and BRCA2 proteins: roles in health and disease. Mol Pathol. 1998; 51:237-247.
81. Yoshida K, Miki Y. Role of BRCA1 and BRCA2 as regulators of DNA repair, transcription, and cell cycle in response to DNA damage. Cancer Sci. 2004; 95:866-871.

82. Nelson HH, Kelsey KT, Mott LA, Karagas MR. The XRCC1 Arg399Gln polymorphism, sunburn, and nonmelanoma skin cancer: evidence of gene-environment interaction. Cancer Res. 2002; 62:152-155.

83. Kang SY, Lee KG, Lee W, Shim JY, Ji SI, Chung KW, Chung YK, Kim NK. Polymorphisms in the DNA repair gene XRCC1 associated with basal cell carcinoma and squamous cell carcinoma of the skin in a Korean population. Cancer Sci. 2007; 98:716-720.

84. Liu K, Jiang Y. Polymorphisms in DNA Repair Gene and Susceptibility to Glioma: A Systematic Review and MetaAnalysis Based on 33 Studies with 15 SNPs in 9 Genes. Cell Mol Neurobiol. 2017; 37:263-74.

85. Chen S, Zhu XC, Liu YL, Wang C, Zhang KG. Investigating the association between XRCC1 gene polymorphisms and susceptibility to gastric cancer. Genet Mol Res. 2016; 15.

86. Hoeijmakers JH. Genome maintenance mechanisms for preventing cancer. Nature. 2001; 411:366-374.

87. Zhao Q, Wang W, Zhang Z, Wang S, Wang M, Zhou J, Gong W, Tan Y, Wang B, Chen G. A genetic variation in APE1 is associated with gastric cancer survival in a Chinese population. Cancer Sci. 2011; 102:1293-1297.

88. Lu J, Zhang S, Chen D, Wang H, Wu W, Wang X, Lei Y, Wang J, Qian J, Fan W, Hu Z, Jin L, Shen H, et al. Functional characterization of a promoter polymorphism in APE1/Ref-1 that contributes to reduced lung cancer susceptibility. FASEB J. 2009; 23:3459-3469.

89. Cao Q, Qin C, Meng X, Ju X, Ding Q, Wang M, Zhu J, Wang W, Li P, Chen J, Zhang Z, Yin C. Genetic polymorphisms in APE1 are associated with renal cell carcinoma risk in a Chinese population. Mol Carcinog. 2011; 50:863-870.

90. Nishioka K, Ohtsubo T, Oda H, Fujiwara T, Kang D, Sugimachi K, Nakabeppu Y. Expression and differential intracellular localization of two major forms of human 8-oxoguanine DNA glycosylase encoded by alternatively spliced OGG1 mRNAs. Mol Biol Cell. 1999; 10:16371652.

91. Lee AJ, Hodges NJ, Chipman JK. Interindividual variability in response to sodium dichromate-induced oxidative DNA damage: role of the Ser326Cys polymorphism in the DNArepair protein of 8-oxo-7,8-dihydro-2'-deoxyguanosine DNA glycosylase 1. Cancer Epidemiol Biomarkers Prev. 2005; 14:497-505. 